\title{
The infestation rate and abundance of insect pests on stored corn in different climatic zones of Turkey
}

\author{
Türkiye'nin farklı coğrafi bölgelerinde depolanmış mısırlar üzerinde rastlanan böcek \\ türlerinin bulaşma oranları ve yoğunlukları
}

Ali Arda IŞIKBER ${ }^{1 *}$

\author{
Hasan TUNAZ ${ }^{1}$ \\ Mehmet Kubilay ER ${ }^{1}$
}

İnanç DOĞANAY ${ }^{1}$

\begin{abstract}
Summary
The occurrence and abundance of insect pests infesting stored-corn in three climatic zones of Turkey (southern (Adana, Mersin and Kahramanmaraş provinces), south-eastern (Şanlıurfa province) and central (Konya province) regions) were studied by taking corn samples from different corn storages in each region every each month from June up to and including November. Seven species, Tribolium castaneum (Herbst), Tribolium confusum Jaquelin du Val., Rhyzopertha dominica (F.), Sitophilus oryzae (L.), Oryzaephilus surinamensis (L.), Cryptolestes ferrugineus (Stephens), and Latheticus oryzae (Waterhouse) belonging to 5 families of Coleoptera were found. The infestation rate of insect species varied with the climatic zones of Turkey. S. oryzae indicated the highest infestation rate $(80 \%)$ in the central region, followed by $T$. castaneum $(40 \%)$ and $C$. ferrugineus $(20 \%)$. T. castaneum and $C$. ferrugineus had the highest infestation rate $(28.5 \%)$ in the south-eastern region while both $T$. castaneum and $S$. oryzae (40\%) had the highest infestation rate in the southern region. In southern region, the total number of insects per $1 \mathrm{~kg}$ corn grain was 33.8 during sampling dates while it was 2.8 and 11.7 insects per $1 \mathrm{~kg}$ corn in central and south-eastern region respectively. These results indicated that the densities of insect species in southern and southeastern region of Turkey were found to be much higher than those in central region where the environment is cooler.
\end{abstract}

Key words: Stored corn, insect density, infestation rate, climatic zone, Turkey

\section{Özet}

Bu çalışmada Türkiye'nin üç farklı coğrafi bölgesindeki (Güney (Adana, Mersin ve Kahramanmaraş illeri), Güneydoğu (Şanlıurfa ili) ve Orta Anadolu (Konya ili) Bölgesi) mısır depolarından hazirandan kasıma kadar her ay mısır örnekleri alınarak depolanmış mısırlar üzerindeki böcek türleri, bulaşma oranları ve yoğunlukları tespit edilmiştir. Yürütülen sürveyler sonunda Tribolium castaneum (Herbst), Tribolium confusum Jaquelin du Val., Rhyzopertha dominica (F.), Sitophilus oryzae (L.), Oryzaephilus surinamensis (L.), Cryptolestes ferrugineus (Stephens), ve Latheticus oryzae (Waterhouse) olmak üzere Coleoptera takımının 5 familyasına bağıı toplam 7 tür tespit edilmiştir. Böcek türlerinin bulaşma oranları bölgelere göre değişiklik göstermiştir. S. oryzae Orta Anadolu Bölgesi'nde en yüksek bulaşma oranına (\%80) sahip olurken bunu sırasıyla $T$. castaneum $(\% 40)$ ve $C$. ferrugineus (\%20) takip etmiştir. Güneydoğu Anadolu Bölgesi'nde T. castaneum ve C. ferrugineus en yüksek bulaşma oranına (\%28.5) sahip olurken Güney Anadolu Bölgesi'nde ise T. castaneum ve S. oryzae (\%40) en yüksek bulaşma oranına sahip olmuştur. Güney Anadolu Bölgesi'nde $1 \mathrm{~kg}$ mısırdaki toplam böcek sayısı 33.8 adet olarak belirlenirken Güneydoğu ve Orta Anadolu Bölgesi'nde $1 \mathrm{~kg}$ mısırda sırasıyla 2.8 ve 11.7 adet böcek olduğu görülmüştür. Bu sonuçlar Güney ve Güneydoğu Anadolu Bölgesi'ndeki mısır depolarındaki böcek yoğunluğu daha serin iklime sahip olan Orta Anadolu Bölgesi'ndeki mısır depolarındaki böcek yoğunluğundan daha yüksek olduğunu göstermiştir.

Anahtar sözcükler: Depolanmış mısır, böcek yoğunluğu, bulaşma oranı, coğrafi bölge, Türkiye

\footnotetext{
${ }^{1}$ Kahramanmaraş Sütçü İmam University, Agriculture Faculty, Plant Protection Department, Avşar Campus, 46100, Kahramanmaraş, Turkey

* Corresponding author (Sorumlu yazar) e-mail: isikber@ksu.edu.tr

Received (Alınış):12.04.2016 Accepted (Kabul ediliş): 03.05.2016 


\section{Introduction}

Corn (Zea mays L.) is considered as one of the most important cereal crops since it has highest genetic yield potential which is used as food, feed, fodder and also serves as basic raw material in industries such as beverage, confectionery, starch, ethanol, oil, cosmetic, pharma, food processing, textile, gum and paper industries. Corn, which is the most produced cereal in the world, has twice more yield per unit area than wheat and barley. In the 2014-2015 season, the corn production in Turkey was about 5.4 million tons and this number was expected to increase to $6.3-6.5$ million tons in the coming 2015-2016 season. The driving force behind this recent increase primarily comes from the increased corn planting in the Southeastern Anatolia Region (Diyarbakır-Batman) and Central Anatolia Region (KonyaKaraman) (Artik et al., 2016). Today corn plays an important role in human nutrition around the world with its large economic value and high energy content. It is rich in carbohydrate, protein, oil and crude fiber contents (FAOSTAT, 2014).

Although production of corn has increased to meet the global demand, several biotic and abiotic factors play an important role in limiting the productivity. It is also plagued with post production storage losses. Among biotic factors contributing for storage losses, insect pests play a major role inflicting 20$30 \%$ damage of corn grain in tropical regions (Haque et al., 2000) due to favorable conditions for their development and poor storage conditions. It has been reported that more than 37 species of insect pests are associated with stored corn (Abraham, 1997). Among these insect pests, Sitophilus oryzae L., (Coleoptera: Curculionidae) (Lucas \& Riudavets, 2000) and Sitotroga cerealella (Oliv.) (Lepidoptera: Gelechiidae) are the major primary insect pests causing quantitative and qualitative losses (Lakshmi Soujanya et al., 2013); starts infestation in the field itself and continues in stored corn. They destroy the seed completely from inside and make them chaffy; and finally seed viability is lost (Hill, 2002).

High environmental temperatures and moisture, along with dockage and broken kernels, provide conditions that accelerate mold and insect development within the grain mass, increasing grain losses. Determining the specific insect pest species found in corn storages is the first step in understanding and controlling insect problems. Knowledge of the occurrence and abundance of insect pests infesting storedcorn in different climatic regions is necessary for integrated pest management programs. The objective of this study was to determine the occurrence and abundance of insect pests infesting stored-corn in three climatic zones of Turkey (southern, south-eastern and central regions) by taking corn samples in bulkcorn grains.

\section{Material and Methods}

\section{The region of stored corn sampling}

Corn samples were taken in three climatic zones of Turkey (southern, south-eastern and central regions), which are indicated on the map of Turkey (Figure 1). From Southern region of Turkey Kahramanmaraş, Adana and Mersin Provinces were selected for corn sampling, while Şanlıurfa and Konya Province were selected from south-eastern and central regions, respectively.

\section{Corn sampling process}

Corn samples were taken in bulk from ten different corn storages (silo and warehouse) per each region every each month from June, 2013 up to November 2013 (5 sampling dates in total) (Figure 2). Five grain samples of approximately $0.2 \mathrm{~kg}$ each were taken randomly by inserting a $1.5 \mathrm{~m}$ open-ended spiral grain probe (Model UST-150, Loyka, Turkey) to a depth of $50 \mathrm{~cm}$ at five different locations of bulk corn grain. Grain temperatures were measure $40 \mathrm{~cm}$ below the corn grain surface using mini NSP-100 portable thermometer and hygrometer with a metal probe (Model NSP-100, LOYKA, Turkey). Adult insects were separated from corn samples with RETSCH grain sieve with 10 meshes (2 mm sieve size, RETSCH GmbH, Germany) and counted. Each grain sample was weighed and insect density was expressed as the number of adult insect per $\mathrm{kg}$ of grain sample. 


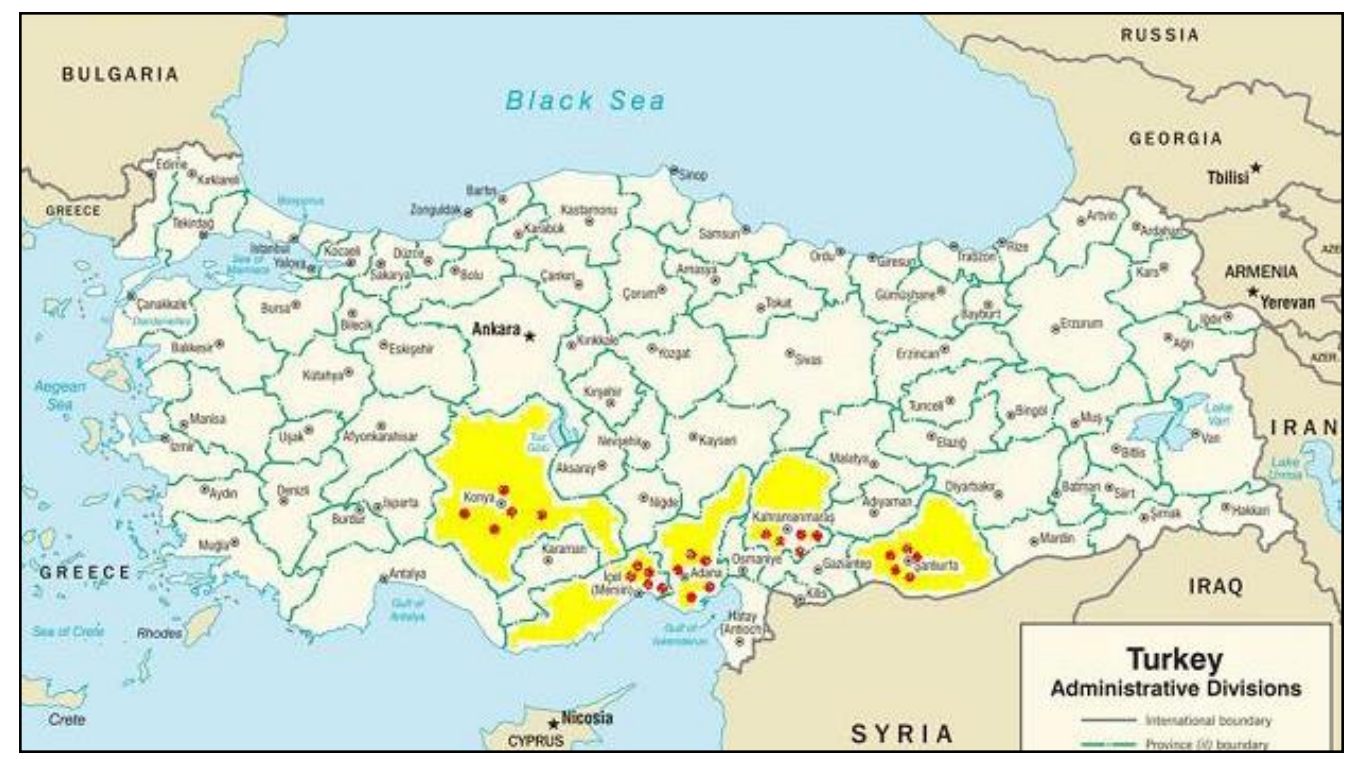

Figure 1. Sampling locations of stored corn in Turkey.



Figure 2. Spiral grain probe used for corn sampling.

\section{Identification of the insects}

All insects captured were identified to species level by using identification keys (Gorham, 1991; Rees, 2004). Specimens of Sitophilus, and initially specimens of Cryptolestes were identified to species level by dissection and examination of the genitalia (Lefkovitch, 1959; Halstead, 1963).

\section{Infestation rate and the number of insect per $\mathrm{kg}$ corn}

We pooled the data for all warehouse and all sample dates to estimate infestation rate of each species and number of insect per $\mathrm{kg}$ corn of each species. The infestation rate of a species was the percentage of all possible samples in which the species occurred; it was estimated as the percentage of samples actually taken in which the species was found. The number of insect per $\mathrm{kg}$ corn for each species was estimated as dividing the total number of insect collected for each species by the total number of corn sample. 


\section{Results and Discussion}

Seven species, Tribolium castaneum (Herbst) and T. confusum Jaquelin du Val. (Fam.: Tenebrionidae), Rhyzopertha dominica (F.) (Fam.: Bostrichidae), Sitophilus oryzae (L.) (Fam.: Curculionidae), Oryzaephilus surinamensis (L.) (Fam.: Silvanidae), Cryptolestes ferrugineus (Stephens) (Fam.: Laemophloeidae) and Latheticus oryzae (Waterhouse) (Fam.: Tenebrionidae) belonging to 5 families of Coleoptera were found (Table 1). T. castaneum and C. ferrugineus were found in all sampling locations while $T$. confusum was determined only in Kahramanmaraş province. $R$. dominica, $O$. surinamensis and L. oryzae were found in Kahramanmaraş, Adana and Şanlıurfa provinces. S. oryzae was detected in all sampling locations except Şanlıurda province. Previous studies carried out to determine the insect species of stored grains in Turkey showed similar insect species to those found in present study (Ergül et al., 1972; Özar \& Yücel, 1981; Dörtbudak \& Aydın, 1984; Yücel, 1988; Isikber et al., 2005; Mert, 2012; Bağcı et al., 2014). Mert (2012) determined seven insect species, namely $T$. castaneum, S. oryzae, C. ferrugineus, T. confusum, O. surinamensis, R. dominica, Sitophilus zeamais (Matsch.), Cryptolestes turcicus (Grouv.) and Sitotroga cerealella (Oliver.) on stored corn in Adana province which is located in southern of Turkey.

Table 1. Insect species determined on corn samples taken from corn storages in five provinces located in three climatic zones of Turkey (live and/or dead)

\begin{tabular}{|c|c|c|c|c|c|c|c|c|}
\hline \multirow[b]{2}{*}{ Location of corn sample taken } & \multirow[b]{2}{*}{ Storage type } & \multicolumn{7}{|c|}{ Insect species determined } \\
\hline & & 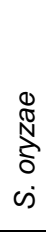 & 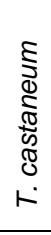 & 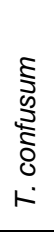 & 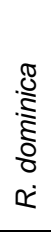 & $\begin{array}{l}\frac{\infty}{\omega D} \\
\frac{D}{\Phi} \\
\tilde{\Phi} \\
\stackrel{\mathbb{S}}{5} \\
\omega \\
0\end{array}$ & & 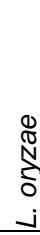 \\
\hline Kahramanmaraş & Warehouse-Opened bulk & - & $\bullet$ & $\bullet$ & $\bullet$ & $\bullet$ & $\bullet$ & $\bullet$ \\
\hline Adana & Warehouse-Opened bulk & $\bullet$ & $\bullet$ & - & $\bullet$ & $\bullet$ & $\bullet$ & $\bullet$ \\
\hline Mersin & Warehouse-Opened bulk & $\bullet$ & $\bullet$ & - & - & - & $\bullet$ & - \\
\hline Şanlıurfa & Warehouse-Opened bulk & - & $\bullet$ & - & $\bullet$ & $\bullet$ & $\bullet$ & $\bullet$ \\
\hline Konya & Silo & $\bullet$ & $\bullet$ & - & - & - & $\bullet$ & - \\
\hline
\end{tabular}

•: Existent of insect species; -: Non-existent of insect species

Grain temperatures for each sampling date in bulked corn in five provinces located in three climatic zones of Turkey are given in Figure 3. Grain temperatures in bulk-corn recorded in Konya province ranged from $17.7^{\circ} \mathrm{C}$ in November to $25.3^{\circ} \mathrm{C}$ in July while those in Adana and Mersin province ranged from $23.6^{\circ} \mathrm{C}$ in November to $32.2^{\circ} \mathrm{C}$ in August and from $24^{\circ} \mathrm{C}$ in November to and $31.2^{\circ} \mathrm{C}$ in July, respectively. In Kahramanmaraş and Şanlıurfa provinces, grain temperatures ranged from $22.4^{\circ} \mathrm{C}$ in November to $32.9^{\circ} \mathrm{C}$ in August and from $19.9^{\circ} \mathrm{C}$ in November to $33.4^{\circ} \mathrm{C}$ in August, respectively. Generally grain temperatures in Konya province located at central region of Turkey were much lower throughout storage period from June to November than those in other provinces located at southern and south-eastern region of Turkey. The optimal temperature for fecundity and development of most stored-product insects is between 25 and $33^{\circ} \mathrm{C}$ (Birch, 1945; Howe, 1965; Lhaloui et al., 1988). It appears that corn grain temperatures in Konya province remained below optimal levels for growth and development of the insects during most of the storage period from June to November. However, those in other provinces (Adana, Mersin, Kahramanmaraş and Şanlıurfa) remained optimal levels for growth and development of the insects during most of the storage period. 




Figure 3. Temperatures for each sampling date in bulked corn in five provinces located in three climatic zones of Turkey.

While $T$. castaneum, S. oryzae and $C$. ferrugineus existed in three climatic zones, $T$. confusum was only found in southern region. S. oryzae exhibited the highest infestation rate $(80 \%)$ in the central region, followed by T. castaneum (40\%) and C. ferrugineus (20\%) (Figure 4). T. castaneum and C. ferrugineus had the highest infestation rate $(28.5 \%)$ in the south-eastern region while both $T$. castaneum and $S$. oryzae $(40 \%)$ had the highest infestation rate in the southern region. Our findings differ somewhat from those of earlier studies, although there are many similarities. Mert (2012) reported that $S$. zeamais, $T$. castaneum, $S$. oryzae, $C$. ferrugineus, $T$. confusum and $C$. turcicus were the most common insect species at stored corn in Adana province by having the highest infestation ratios throughout sampling periods, respectively. These results were parallel to those obtained from our study except insect species of $S$. zeamais and $C$. turcicus. In the present study, Trogoderma granarium Everst (Col.: Dermestidae) that is subject to quarantine was not found any infestation on stored corn in all sampling locations although several studies were also reported that stored wheat was highly infested by $T$. granarium in south-eastern region of Turkey (Ergül et al., 1972; Yücel, 1988; Isikber et al., 2005).

Rhyzopertha dominica had the highest number of insect per $1 \mathrm{~kg}$ corn in Kahramanmaraş province followed by $T$. castaneum in Kahramanmaraş and Urfa provinces. The total density of insect species on stored corn in Kahramanmaraş province (33.8 insects per $1 \mathrm{~kg}$ corn) was found to be higher than those in other sampling locations. In southern region, the total number of the insects per $1 \mathrm{~kg}$ corn grain was 33.8 during sampling dates while it was 2.8 and 11.7 insects per $1 \mathrm{~kg}$ corn in central and south-eastern region, respectively (Figure 5). These results indicated that the densities of insect species in southern and south-eastern regions were found to be much higher than those in central region of Turkey. This may be because of the environmental conditions, which are hot and humid, in southern and south-eastern regions and differences in the central area where the environment is cooler. 


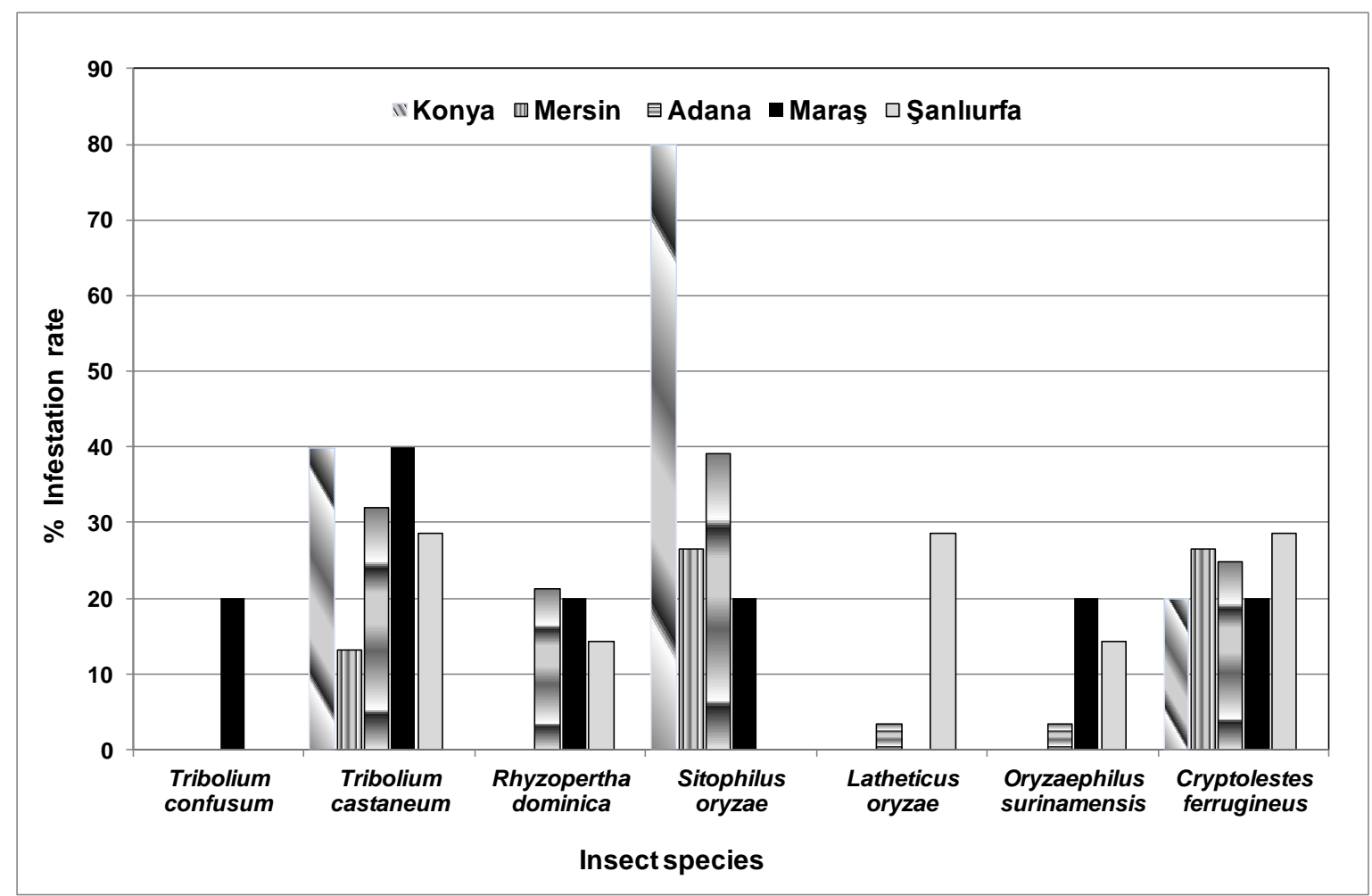

Figure 4. Infestation rate of each insect species collected from corn sample taken by spiral grain probe in five provinces located in three climatic zones of Turkey.

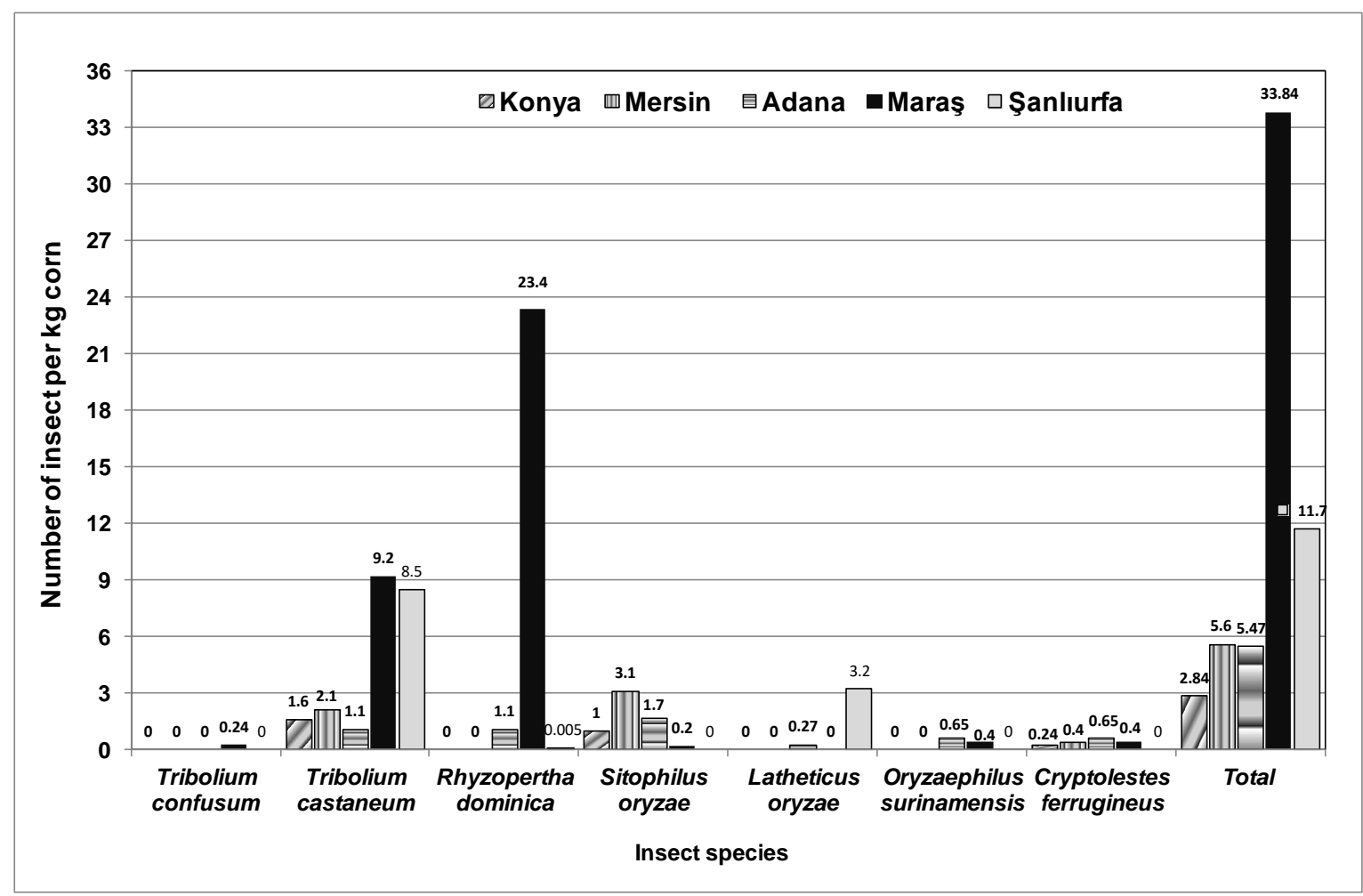

Figure 5. Number of insect per $1 \mathrm{~kg}$ corn for each insect species collected from corn sample taken by spiral grain probe in five provinces located in three climatic zones of Turkey. 


\section{Conclusions}

In this study, it was obvious that the infestation ratio and density of insect species determined on stored corn varied considerably with geographic regions and climatic zones. Generally, the densities of insect species in southern and south-eastern regions of Turkey were found to be much higher than those in central region where the environment is cooler. Consequently, the results obtained from present study suggest that southern region of Turkey, would be at higher risk for stored corn insect pests compared with central and south-eastern regions of Turkey, which could cause significantly higher damage and reduction in corn grain value.

\section{Acknowledgement}

This study was a part of a project granted by The Scientific and Technological Research Council of Turkey (TÜBITAK) with project number 1120304.

\section{References}

Abraham, T., 1997. Arthropods associated with stored maize and farmers' management practices in the Bako area, Western Ethiopia. Pest Management Journal of Ethiopia, 1: 19-27.

Artik, N., N. Konar, M. Özkan \& M.L. Çakmakçi, 2016. Aflatoxin and genetically modified organisms analysis in Turkish corn. Food and Nutrition Sciences, 7: 138-148

Bağcı, F., A. Yilmaz \& S. Ertürk, 2014. Insect pest species in grain warehouses in Ankara province. Plant Protection Bulletin, 54(1): 69-78. (Abstract in English)

Birch, L.C., 1945. The influence of temperature, humidity and density on the oviposition of the small strain of Calandra oryzae L. and Rhyzopertha dominica FAB. (Coleoptera). Australian Journal of Experimental Biology \& Medical Science, 23: 197-203.

Dörtbudak, N. \& M. Aydın, 1984. An investigation on the results of the storage losses of wheat, caused by insects during various storage periods in Central Anatolia. Plant Protection Bulletin, 24 (2): 94-111. (Abstract in English)

Ergül, C., A. Dörtbudak \& A. Akülke, 1972. Investigations on the insect of stored grain, grain products and leguminosae in the East and South East part of Turkey. Plant Protection Bulletin, 12(2): 129-143. (Abstract in English)

FAOSTAT, 2014. Food and Agricultural Organization of the United Nation. (Web page: http://faostat.fao.org/site/291/default.aspx) (Date Accessed: Oct. 2014)

Gorham, J.R., 1991. Insect and Mite Pests in Food. U.S.D.A., Agriculture Handbook No.655. 747p.

Haque, M.A., H. Nakakita, H. Ikenaga \& N. Sota, 2000. Development inhibiting activity of some tropical plants against Sitophilus zeamais Motschulsky (Coleoptera: Curculionidae). Journal of Stored Products Research, 36: 281287.

Halstead, D.G.H., 1963. The separation of Sitophilus oryzae (L.) and S. zeamais Motschulsky (Col.: Curculionidae), with a summary of their distribution. Entomologists' Monthly Magazine, 94: 72-74.

Hill, D.S., 2002. Pests of Stored Food Suffs and Their Control. Kluwer Academic Publication., Boston, p.55-63.

Howe, R.W., 1965. Losses caused by insects and mites in stored foods and feeding stuffs. Nutrition Abstracts and Reviews, 35(2): 285-303.

Isikber, A.A., H.Ü. Özdamar \& A. Karci, 2005. Determination of insect species and their infestation rates on stored wheat in Kahramanmaraş and Adıyaman province. KSU Journal of Science and Engineering, 8(1): 107-113. (Abstract in English)

Lhaloui, S., D.W. Hagstrum, D.L. Keith, T.O. Holtzer \& H.J. Ball, 1988. Combined influence of temperature and moisture on red flour beetle (Coleoptera: Tenebrionidae) reproduction on whole grain wheat. Journal of Economic Entomology, 81: 488-489. 
Lakshmi Soujanya, P., J.C. Sekhar, P. Kumar \& S.B. Suby, 2013. Use of plant leaf powders to assess and manage Sitophilus oryzae (L.) (Coleoptera: Curculionidae) in stored maize grain. Indian Journal of Plant Protection, 40: $1-4$

Lefkovitch, L.P., 1959. A revision of the European Laemophoeinae (Coleoptera: Cucujidae). Transactions of The Royal Entomological Society of London, 111: 95-118.

Lucas, E. \& J. Riudavets, 2000. Biological and mechanical control of Sitophilus oryzae (Coleoptera: Curculionide) in rice. Journal of Stored Products Research, 38: 293-304.

Mert, A., 2012. Harmful Insects and Mites of Stored Seed Corns in Adana Province, Turkey. Çukurova University, Institute of Natural and Applied Sciences, Department of Plant Protection. 61p. (Abstract in English)

Özar, A.G. \& A. Yücel, 1981. Survey studies on the stored grain pests in the Southeast Anatolia Region. Plant Protection Bulletin: 22(2): 89-98. (Abstract in English)

Rees, D., 2004. Insects of Stored Products. CSIRO Publishing, Collingwood, Victoria, Australia. 181p.

Yücel, A., 1988. Investigation on determining flour beetles and their damages in meal factories and mills in Southeastern Anatolia. Plant Protection Bulletin, 28(1-2): 51-77. (Abstract in English) 